IRA-International Journal of Education \& Multidisciplinary Studies

ISSN 2455-2526; Vol.04, Issue 01 (2016)

Institute of Research Advances

http://research-advances.org/index.php/IJEMS

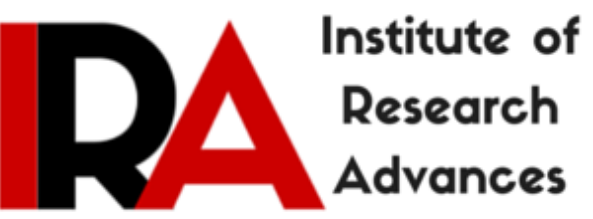

\title{
Role of Yoga in Pacifying Terrorism
}

\author{
Dr. Kalpana Gupta* Mrs. Pratima Singh*
}

*Assistant Professor, Faculty of Education,

Dayalbagh Educational Institute, Dayalbagh, Agra, India.

DOI: http://dx.doi.org/10.21013/jems.v4.n1.p9

\section{How to cite this paper:}

Gupta, K., \& Singh, P. (2016). Role of Yoga in Pacifying Terrorism. IRA

International Journal of Education and Multidisciplinary Studies (ISSN 2455-

2526), 4(1). doi:http://dx.doi.org/10.21013/jems.v4.n1.p9

(C) Institute of Research Advances

\section{(cc) BY-NC}

This works is licensed under a Creative Commons Attribution-Non Commercial 4.0 International License subject to proper citation to the publication source of the work.

Disclaimer: The scholarly papers as reviewed and published by the Institute of Research Advances (IRA) are the views and opinions of their respective authors and are not the views or opinions of the IRA. The IRA disclaims of any harm or loss caused due to the published content to any party. 


\title{
The Religion of Love
}

\author{
"My heart holds within it every form, \\ it contains a pasture for gazelles, \\ a monastery for Christian monks. \\ There is a temple for idol-worshippers, \\ a holy shrine for pilgrims; \\ There is the table of the Torah, \\ and the Book of the Koran. \\ I follow the religion of Love \\ and go whichever way His camel leads me. \\ This is the true faith; \\ This is the true religion."
}

(Poet: Ibn Arabi)

Love is the base of the universe; it is the cause of the existence of creatures on the earth. This is one of the basic needs of human beings. Everyone wants peace and love but lust, materialistic desires, bubble fame, wealth, misguided patriotism lead to destruction and chaos in the world. God has given human beings no religion, these are human beings who put label of religion on themselves and call God by different names Allah, Ishwar, Jesus and so on. God is one and all the religion leads us to same path. No religion leads us to destruction, violence and bloodshed. No wars and terror should be launched in the name of religion. Some fanatic Muslims believe in JIHAD, according to them Islam is in danger and for the safety and existence of Islam; Muslims should stand up together and fight. This fanaticism should not be sprouted on this earth. Generally an average person's level of consciousness is rather low. He is enslaved to life and lives on false hopes and illusions.

He spends his life in ignorance, experiencing joy and sorrow, success and failure, love and grief without ever really coming to the ultimate realization. Under the influence of sensation and passion, people commit errors which they subsequently regret. They delude themselves by looking for peace, happiness and self accomplishment through the pleasure of the senses. Materialism does not give us peace of mind and inner calm. There are so many examples throughout the world of people who have everything they need materially but they are nevertheless unhappy, restless and tormented.

\subsection{Meaning and Definition of Yoga}

The word yoga comes from the Sanskrit root 'YUJ' meaning 'to join'. It designates 'the joining of the lower human nature to the higher in such a manner that it allows the supreme universal spirit to obtain relief from pain and suffering'. Yoga is a broad discipline which consists of eight limbs viz. Yama, Niyama, Asana, Pranayama, Pratyahara, Dharana, Dhyana, and Samadhi.

Yoga is a discipline to improve or develop one's inherent power in a balanced manner. It offers the means to attain complete self-realization. Yoga can therefore be defined as a means of uniting the individual spirit with the universal spirit of God. According to Maharishi Patanjali, Yoga is the suppression of modifications of the mind.

Yoga teaches self discipline and self control. Through constant practice of yoga one can overcome all difficulties and eradicate all weaknesses. Pain can be transmitted into bliss, sorrow into joy, failure into success and sickness into perfect health. Determination, patience, persistence lead us to the goal (Bhagwad Geeta).

\subsection{What is Terrorism?}

Terrorism is doing or getting the things done by the means of terror or force. It has been seen that in almost all the terrorist activities Muslim people are found involved. Group of such people is now termed as Radical Islam. Islamic fundamentalism or Radical Islam is a description used in relation to Islamic ideology. Radical Islam is a militant, politically activist ideology whose ultimate goal is to 
create a worldwide community, or caliphate, of Muslim believers. Determined to achieve this new world order by any means necessary, including violence and mass murder, radical Islam is characterized by its contempt for the beliefs, practices, and symbols of other religious traditions. This intolerant creed is cited by Islamists as the philosophical justification for their terrorism.

Radical Islam's kinship with terrorism, and its willingness to use violence as a means to its ultimate ends, is clearly spelled out in a training manual produced by the radical Islamist terror group al Qaeda. This publication candidly says:

"[An] Islamic government would never be established except by the bomb and rifle. The confrontation that Islam calls for with these godless and apostate regimes, does not know Socratic debates, Platonic ideals nor Aristotelian diplomacy. But it knows the dialogue of bullets, the ideals of assassination, bombing, and destruction, and the diplomacy of the cannon and machine-gun. The young came to prepare themselves for Jihad [holy war], commanded by the majestic Allah's order in the holy Koran."

Scholar of Middle East affairs Martin Kramer further describes the goals of radical Islamists:

"The idea is simple: Islam must have power in this world. It is the true religion-the religion of God-and its truth is manifest in its power...."

Exemplary figures of Islamic fundamentalism are Sayyid Qutb, Abdul Ala Muoddi and Issar Ahmad. Wahhabism is often described as the main cause of Islamic fundamentalism. According to academic John Esposito, one of the most defining feature of Islamic Fundamentalism is belief in the 'Reopening' of the gates of Ijtihad ("Independent Reasoning" used in reaching a legal decision in Sunni law).

Graham Fuller describes Islamic Fundamentalism not as distinct from Islamism but as a subset, 'the most conservative element among islamists'. Its strictest form includes 'Wahhbism, sometimes also referred to as Salafiyya. For fundamentalists the law is the most essential component of Islam, leading to an overwhelming emphasis upon jurisprudence, usually narrowly conceived.

\subsection{Islamic Fundamentalism Groups}

Islamic Fundamentalism groups include Al-Queda, Abu Sayyaf, Ansar-al-Islam, Armed Islamic group of Algeria, Army of Islam, Bokoharam, Taliban, Egyptian Islamic, Jihad, Lashkar-e-Taiba, Jaish-eMohammed, Jemaah Islamiyah, Harkal-ul-jihad al-Islami, Harkar-ul-mujahideen, Indian Mujahideen, Ismalic state of Iraq and the Levant Tehrik-i-Taliban Pakistan etc.

Islam is not Radical, some terrorists are Muslims. ISIS's barbaric brutality depicts in a released video which shows killing of Jordanian Muslim fighter pilot Muath al-kasashbeh. He was flying sorties or part of the U.S. organized coalition to destroy ISIS. The way he was killed sets a new law in the depravity. ISIS militants first chained kasashbeh in a cage and then poured flammable fluids into his cell. With kasashbeh watching an ISIS militant lit the fluid on fire. Then while kasashbeh was burning to death, they dropped debris on him, like brick masonry. Finally they drove a bulldozer over him several times. ISIS militants are not only killing people of the other religion but Muslims too. In 2014 in Iraq alone at least 4325 Muslim civilians were slaughtered by ISIS who were innocent. ISIS is murdering an average 12 Muslim civilian men, women and children every single day. As per a United Nations report released in September 2014, ISIS targeted Muslims, both Sunnis and Shias, who refused to submit to it. Three Sunni nurses were executed in Mosul for refusing to treat ISIS fighters. In Syria as per the London based Syrian Human Right Committee, in December 2014 alone ISIS killed 49 civilians, executing almost everyone in front of their families. In March 2015 Islamic State militants in Yemen carried out five suicide bombings at the Badr and al-Hashoosh Shia mosques during prayers in which 137 innocent people died and 345 injured. Recently Boko Haram set off bombs at a mosque and restaurant in Nigeria. Fifty-one were killed along with 67 injured. In Potiskum, militants killed six in a suicide bombing. Later militants killed nine people and burned thirty-two churches and three hundred houses in cities in the Northeast. In June 2015, 19 militants and seven soldiers were killed by suicide bombing and exchange of gunfire in North Waziristan, Pakistan. 


\subsection{Rational Radicalism................Why Do People Become Terrorists?}

Most studies of the causes of Islamism offer a grievance based explanation implicitly rooted in functionalist social psychology accounts of mass behaviour, which view collective action as derived from exogenous structural strains that create individual frustration and motivation for deviant social behaviour. Structural strains such as modernization, industrialization, economic crisis cause psychological discomfort which in turn produces collective action. Sometimes innocent people are terrorized and blackmailed to such an extent on the name of their family and dear ones that they are forced to join and execute terrorist activities.

Children of poor, unprivileged section of Islamic faith are trapped since their early childhood. They are taught the false meaning of the religious teaching. Their brain wash is done in such a way that these innocent people are misguided on the name of religion and faith and they consider it their foremost and sacred duty to kill humanity on the name of Islam and Jihad.

Poverty and unemployment forces the uneducated and helpless youth to get indulged in such inhuman activities to earn money and bread and butter for their families. These young men are given huge amount of money and an assurance of safety and expenditure for their families also.

Sometimes some innocent young children are trapped and dragged in these activities. But after that these children are not given a second chance to correct themselves. This road is a one way lane, in which once entered, there is no coming back. The society doesn't accept that person and judiciary don't give him the chance to correct himself. Subsequently these young boys are left with no option but to be there.

Justice delayed is Justice denied. Sometimes the injustice and brutality done to people by police, society, government system or religion makes the youth so much rebellious to take revenge that they become furious and become part of terrorist groups. This is enhanced when they do not find justice. Many a times delay in justice makes the young blood impatient and they choose this path of terrorism.

Attraction towards growing materialism and ultra luxurious life and at the same time negligence of parents and guardians drags the youth of high profile society into the ill professions of smuggling, human trafficking and terrorism.

Psychological discomfort, feeling of loneliness and alienation also push the young people into such activities.

The main reason behind all these is the lack of literacy, education and awareness. With a few exceptions most of these people belong to unprivileged, poor section of the society.

\subsection{How Yoga Calms Mind, Body and Soul}

Yoga is not a religion; it is a way of living whose aim is 'a healthy mind in a healthy body'. Man is a physical, mental and spiritual being; yoga helps promote a balanced development of all the three. Other forms of physical exercises, like aerobics, assure only physical well-being. They have little to do with the development of the spiritual or astral body. Yogic exercises recharge the body with cosmic energy; this facilitates:

- Attainment of perfect equilibrium and harmony.

- Promotes self- healing.

- Removes negative blocks from the mind and toxins from the body.

- Enhances Personal power.

- Increases self-awareness.

- Helps in attention focus and concentration, especially important for children.

- Reduces stress and tension in the physical body by activating the parasympathetic nervous system.

- The aspirant feels rejuvenated and energized.

- Relieves body from daily stress, maintains health, and stay in shape. 
Thus, Yoga bestows upon every aspirant the powers to control body and mind. Yoga is universal, it is a path on which all those who have determination may, whatever their age, social status, belief or religion. Yoga is accessible to everyone. There is just one condition; it must be practiced regularly under proper guidance. Yoga brings hope and self confidence to all those who are disappointed by their materialistic life or are bound up in all sorts of problems. Yoga teaches us to live reasonably and avoid uselessly squandering our energy; it also shows us how to exercise self control and preserve a positive attitude towards life.

If we want to attain higher level of concentration and meditation we will have to practice yoga. As the proverb goes, 'well begin is half done'. If all the human beings adopt Yama, Niyam, Asan and Pranayam in their daily life, they will definitely feel a positive change in their lives. It will give them a way to relax and concentrate despite their busy and fast life.

\subsubsection{Objectives of the Study}

$>$ To find out the opinion of teacher trainees about the significance of yoga education in pacifying Radical Islam in India.

$>$ To find out the opinion of teacher trainees about significance of yoga education in developing the following ethical values among fundamentalists like:

- Respect for human life

- Justice

- Tolerance

- Attitude and skill required for living in harmony with others

- Cooperation

- Social responsibility

- Commitment for democracy

- Resolving conflicts non violently

- Development of feeling of fatherhood of god and brotherhood of man.

\subsubsection{Methodology of the Study}

Descriptive Survey method has been used in the present study.

\subsubsection{Selection of the Sample}

Under the simple random selection procedure, 300 units of teacher trainees from Dayalbagh Educational Institute, Deemed University, Dayalbagh, Agra, have been taken up as the sample of the study. To make these teacher trainees acquainted of yoga and understand the concept, a 10 days Yoga camp was organized in the faculty of education, Dayalbagh Educational Institute, Dayalbagh, Agra; in the month of August 2015 (this camp is organized every year in the faculty). After the camp, the opinion of the teacher trainees was taken through opinionnaire.

\subsubsection{Tool Used}

A self prepared opinionnaire has been used to determine significance of yoga education in pacifying Terrorism in India. The validity of the tool is based on face validity. The coefficient of reliability of the tool was found 0.68 by using split half method and by using Spearman Brown formula it was 0.76 . It is determined that the tool used is reliable.

\subsubsection{Scoring of the Opinionnaire}

The opinionnaire consisted of 30 items, each having three options for answering the questions- Yes, No and Uncertain. 29 items were based on nine valued mentioned in the objectives of the study and the last 30th item consisted of a concluding statement on opinion of teacher trainees about the significance of yoga education in pacifying Terrorism. Answers related to each question of each aspect were noted in a table. Finally percentage of each aspect was calculated to draw results. 


\subsubsection{Findings and Conclusions}

A global view of the percentage scores of the opinion of teacher trainees about significance of yoga education in developing ethical values and pacifying Terrorism.

Table 1. Percentage scores of the opinion of teacher trainees regarding the development of values through yoga Education:

\begin{tabular}{|l|l|c|c|c|}
\hline S.NO. & \multicolumn{1}{|c|}{$\begin{array}{c}\text { Yoga education and development of values to } \\
\text { pacify Terrorism }\end{array}$} & \multicolumn{3}{|c|}{ \% } \\
\cline { 3 - 4 } & & \multicolumn{1}{|c|}{ Yes } & No & Uncertain \\
\hline 1. & Respect for human life & 89.33 & 1.33 & 9.33 \\
\hline 2. & Justice & 79.0 & 3.66 & 17.33 \\
\hline 3. & Tolerance & 84.66 & 4.66 & 10.66 \\
\hline 4. & $\begin{array}{l}\text { Attitude and skill required for living in harmony with } \\
\text { others }\end{array}$ & 82.0 & 5.66 & 12.33 \\
\hline 5. & Cooperation & 77.0 & 6.0 & 17.0 \\
\hline 6. & Social responsibility & 87.0 & 4.33 & 8.66 \\
\hline 7. & Commitment for democracy & 90.66 & 5.6 & 4.33 \\
\hline 8. & Resolving conflicts non violently & 71.66 & 5.33 & 23.0 \\
\hline 9. & $\begin{array}{l}\text { Development of feeling of fatherhood of god and } \\
\text { brotherhood of man. }\end{array}$ & 68.0 & 7.3 & 24.66 \\
\hline
\end{tabular}

After observing the above table a global view of the percentage of scores of the opinion of teacher trainees about the significance of yoga education in developing ethical values among fundamentalists by pacifying violence, it is determined that a majority of teacher trainees opine that yoga education can be highly useful in shaping the behaviour of fundamentalists. More than $80 \%$ teacher trainees believe that yoga education is helpful in the development of respect for human rights, tolerance, attitude and skills required for living in harmony with others and for Social responsibility and commitment for democracy. Above $68 \%$ teacher trainees believe that yoga education is helpful in the development of values of justice, cooperation, resolving conflicts non-violently and development of feeling of fatherhood of god and brotherhood of man.

In a nutshell it is asserted that yoga education plays a significant role in pacifying Terrorism.

\subsection{Some Suggested Activities of Yoga Education to Nip the Evil in Bud i.e. Fundamentalism}

No one is born as terrorist. Circumstances make a person to do violence. Now-a-days world is moving fast. Desires of human beings for materialism are growing in leap and bound. There must be done something which prevents human beings from becoming violent and materialistic. Yoga education is such a way to create peace loving, harmonious, calm and compassionate human beings who stay composed even in difficult situations and do not turn into fundamentalists. Following activities can be taken up in society and schools since beginning-

- Morning Prayer and some thoughts to do good to all creatures on earth.

- Practicing Anulom-Vilom, Kapalbhati and Bhramri Pranayam to keep mind and body calm.

- Some asanas like Surya namaskara, trikonansan, padmasana, gaumukhasana, halasana, sarpasana etc. to be practiced to keep body in control because 'a sound mind resides in a sound body'.

- Meditation session for 2-4 minutes to attain concentration.

- Training of 'Yam' should be given right from the beginning to young children in all the educational institutes and at homes also. It inculcates the feelings of love, peace and tolerance.

- Time to time lectures (Satsang) or demonstration session of yoga should be organized to promote this noble cause.

- 'Niyam' (discipline) should also be practices in daily life to keep the mind and body at ease and at peace. 
- 'Jesa khayega anna, wesa banega mann'. Keeping this in mind children should be encouraged to adopt 'satvik' and vegetarian food. This would develop compassion in the young minds towards the other creatures.

\subsection{Conclusion}

Yoga is not the entity of any particular religion, rather it is a discipline, which if followed regularly brings peace, ease and happiness and satisfaction in life. It is now necessary to pay heed to it and make it an essential part of curriculum internationally. The world needs it to defeat the monster of terrorism. It is said that precaution is always better than cure. So instead of fighting the radical Islam and punishing the terrorists later, the upbringing and training of children should be such that no false greed or hope can deviate them from the path of love for humanity.

Its current example is the celebration of International Yoga Day on 21st June 2015 by the international community. It can be called the beginning in this direction. If all the countries would join hands and will promote the practice of yoga, the day is not too ahead when world would become a peaceful place to live in.

\section{References:}

Ananda, Sri. 2005. 'The complete book of yoga: harmony of body and mind'. Orient paperbacks, Delhi.

Nawaz, Maajid. October 2013. 'Radical: My Journey Out Of Islamist Extremism'. Lyons Press; First Edition

Burke, Jason. 2003. 'Al-Qaeda: The True Story of Radical Islam' I.B. Tauris Publishers.

Sterns Mary Nurrie., Sterns Rick Nurrie 2015. 'Yoga Mind, Peaceful Mind Simple Meditations for Overcoming Anxiety' .New harbinger publications.

'Issues Radical Islam' retrieved from the link:

http://www.discoverthenetworks.org/guideDesc.asp?catid=107\&type=issue

'Islamic fundamentalism' retrieved from the link:

https://en.wikipedia.org/wiki/Islamic_fundamentalism

Friedeberger, Julie. 2011. The Healing Power of Yoga: For Health, Well-Being and Inner Peace', Motilal Banarsidass Publishers; 1 edition.

http://thehill.com/blogs/blog-briefing-room/news/246879-graham-radical-islam-is-running-wild-inmiddle-east

http://www.thedailybeast.com/articles/2015/02/06/there-s-no-such-thing-as-radical-islam-there-areonly-terrorists-who-are-muslim.html 